\title{
The Principal's Role as A Supervisor in Improving Teacher Performance at SDIT Baitul Jannah Bandar Lampung Performance
}

\author{
Budi Suhati Lestari', Sowiyah ${ }^{2}$, Dedy Hermanto Karwan ${ }^{3}$ \\ ${ }^{1,2,3}$ Magister Educational Administration of University of Lampung \\ ${ }^{*}$ Corresponding author:
}

Email: budisuhatil@gmail.com

\begin{abstract}
Abstrak: Supervising is a cooperative service. Supervising can be understood to be helpful in two directions as it is applied. In other words, the supervised instructor and the supervisor themselves are promoted and reorganized so that, in turn, teachers may become professionals. This study was conducted to reveal: 1) The role of the Principal in Learning Preparation to enhance teacher success as an Instructional Supervisor. 2) The role of the Principal in integrating learning to increase success as an Instructional Supervisor. 3) The role of the Principal in Learning Assessment to enhance teacher efficiency as an Instructional Supervisor. The role of the Principal as a supervisor in improving teacher performance at SDIT BaitulJannah has been well achieved from the results of the study but needs to be improved again. The Principal has done his best to guide, direct, design, inspire, assess, and maintain good ties from within and outside the school. However, there were some hurdles, including the short-term supervision of all teachers. While support is required, namely the teachers' willingness to obtain guidance from SDIT Principal BaitulJannah, active involvement of students in school activities, help from superiors, and good relations between school members.
\end{abstract}

Keywords: the role of principal, supervision, learning quality

\section{INTRUDUCTION}

Education is a concerted attempt to develop human capital. In implementing this education, the school becomes one of the facilities, and teachers as teaching staff in schools are the main component of human capital to be sustainably fostered and developed. Supervision is required to monitor and strengthen the teaching and learning process carried out by the teacher. Furthermore, this supervisory practice is intended to develop the mentality of teachers so that they are dedicated so that they can fulfill their roles and duties professionally.

According by Sergiovani and Starrett, quoted in Mulyasa (2013), supervision is a method that is explicitly structured to help teachers and supervisors learn their everyday school roles and use their experience and expertise to provide customers with better service. As a more successful learning society, older learners and schools. It can be understood from this definition of supervision that supervision can provide advantages in two ways, namely, the supervised instructor and the supervisor itself. They are encouraged and reorganized so that, in turn, they can be used to lead teachers in education to become professional figures. If he / she has enough integrity, a person can work professionally. A individual will not be able to work professionally if they only fulfill one of the competencies required.Likewise with teachers, if he has mastered teacher competencies that have been determined by the government, as specified in the Law on Teachers and Lecturers, Article 8 of the Republic of Indonesia, a teacher will be able to perform his duties and responsibilities 
professionally

A teacher faces many difficulties and barriers that emerge in the field, both internally and externally, when implementing these competencies. To provide solutions, the teacher needs support and encouragement from the supervisor. This is in line with the aims of instructional supervision implementation, as described in Fathurrahman by Glickman, which is to help teachers improve their abilities to achieve the learning objectives set out for their students. In line with this view, Brigs in saga la emphasized that activities of educational supervision organize, motivate, and direct the growth of teachers. Article 57 of PP No 19 of 2005 states that supervision requires the supervision by managers and supervisors of academic units and representatives of education units on a daily and continuous basis. It can also be said that the government's supervisory roles are managers and leaders in the field of teacher efficiency. In order to perform these tasks, the government has defined standards of competence which both roles should possess. Permen Diknas No. 13 of 2007 sets out the concept of the applicable competence level.

The principal as supervisor has an important role in the growth and advancement of schools in increasing teachers' capacity to handle learning experiences in schools. He must also carry out correct and substantial monitoring and the right strategies and approaches. Coaching by the teachers 'school principal will boost teachers' efficiency and engagement in the education world. Teachers are often helped to create learning innovations for students so that they are able to absorb the importance of learning values to the highest possible degree and to develop student identities so as to make learning innovations the standard of education in their institution. The director is not only the learning leader, he also leads all of the leadership positions in a school such as planning, professional coaching, teamwork and assessment. In this age of decentralization, the leadership of educational establishments is autonomous and gives them the key flexibility to run his dreams of fulfilling his vision of leadership. As a wise supervisor, the head should prepare to work together to solve the problems that emerge among teachers and work together to change plans and emerging new situations.

Our instructor today also has a far from optimal condition. The content can first be well absorbed conceptually by students. They were not however able to cultivate an up-to - date attitude in their actions. Muhammad Maftuh Basyuni says In Muhaimin (2005:23), religious education is currently taking place rather than love and psychomotor. Many teachers still haven't introduced their learning instruments in full. Also teachers are unable to create learning instruments, copying them only from others, so that research tasks go without simple concepts or come out of ideas. This means that the learning goals are not reached. Third, several teachers are also not using state-of-the-art teaching aids, so students feel dull and bored.

Researchers have found schools of excellent growth, schools which relate to integrated Islamic schools, from preliminary observations made by researchers, which, of course, enable or require students to cover their genitals. The number of students who rise every year demonstrates public confidence. In order to increase the quality of the school, the school has a sound performance goal. Their teachers see parents' convictions taking their children to Baitul Jannah. From the preliminary observations, the researcher saw SDN Sukoanyar 1 as having an excellent working culture with high discipline, both students, teachers and other educational workers. The principal often oversees learning events through school visits or family meetings. Based on the above conditions, the researcher wanted to know the degree to which Academic Supervision at SDIT Baitul Jannah Bandar Lampung improved teacher performance.

In this report, given the position of the principal so much that must be done, the researcher will concentrate more on the principal's part as an instructional supervisor in enhancing teacher performance. 


\section{METHODS}

The research uses qualitative methods to understand the significance of events and their relationships with individuals in certain situations in a phenomenological manner. Meoloeng (2014: 78), in his book, explains: qualitative analysis is a research paradigm for explaining and evaluating events, people's actions, or a situation in a particular place in narrative detail and scope. Qualitative design was chosen because this research object is the activity or action of someone at SDIT BaitulJannah, mainly knowing the role of principal as academic supervisor in improving teacher performance.Collecting data is achieved by interviews, observations, documentation or in combination, and collecting information can create written records.

\section{RESULT AND DISCUSSION}

Several details of the academic supervision of SDIT BaitulJannah School Principals were found in the data presented above. The findings are as follows:

1. Preparation of the Principal as Instructional Supervisor to Boost Teacher Efficiency at SDIT Baitul Jannah. In order to be successful in the implementation of supervision, a program plan is required that involves a range of tasks or activities carried out by the Principal in the performance of supervision. Planning is basically a process of decision-making on a variety of alternatives (options) for goals and strategies to be adopted in order to achieve the desired objectives and to track and assess the outcomes of their implementation, which are carried out systematically and continuously.

Based on the results of the study, the principal's academic supervision work program at SDIT BaitulJannah was planned by the principal and the vice-principal. Generally speaking, the practice of job programs applies to the 8 National Education Requirements. The job schedule consists of an annual plan and a semester programme. The annual program and semester program comprises supervisory roles and functions, such as evaluation, coaching and monitoring. The supervisory function involves learning management preparation activities, the implementation of learning and the assessment of student learning outcomes.

The findings of the above research suggest that the preparation of the Principal Supervision Program and its team is consistent with the outcomes when the supervision was carried out. This can be seen clearly from the construction of the principal instructional supervision program, which provided material related to teacher performance, namely teaching preparation, learning execution, and learning outcome evaluation in evaluation, coaching, and monitoring practices.

According to Roger A. Kauffman, quoted by Nanang, preparation is a method to establish the goals or objectives to be accomplished and to define the routes and resources required to achieve the goal as quickly and effectively as possible. Planning is the act of determining in advance what to do, how to do it.

Do it, what do you have to do, and who does it. For this purpose, preparation needs data and knowledge so that decisions made cannot be isolated from future challenges.

In the context of the definition put forward by Roger A. Kauffman, the planning of the principal's academic supervision program has been carried out by the process. At the very least, the activity defined what was done, how to do it, the time of implementation, the facilities needed and how to assess the progress of its implementation.

Compile the plan systematically and on the basis of the findings of the study of previous learning supervision. This suggests that the Principal, as a leader, has recognized that any action conducted is aimed at enhancing the process and learning outcomes by pointing to improvements in teaching conduct for the better.

Academic supervision practices are important activities to enhance the quality of learning. The principal, as supervisor, is responsible for encouraging teachers to enhance their performance. 
Teachers in the management of the learning process should run well so that the quality of learning can always be enhanced. Therefore, in order to achieve the maximum results from a job, the task must be properly organized in a program; from the Islamic point of view, it is important to control the matters to be carried out in a plan or schedule.

Baitul Jannah SDIT has prepared a program of academic supervision to enhance the quality of teaching. This is achieved through a combination of counseling, encouragement, and helping teachers grow their ability to navigate the teaching and learning process to enhance the success of teachers. The tasks of the Principal in the collection of the supervision program referred to above are a set of activities related to the application of academic supervision. This is supported by Glikman 's view that academic supervision is "a set of activities designed to help teachers improve their ability to navigate the teaching and learning process in order to achieve learning objectives.

2. Introduction of the Principal as Instructional Supervisor for Enhancing Teacher Performance at SDIT BaitulJannah

The professional standard of teacher training has a significant effect on the quality of learning. Therefore, attempts to enhance the professional capacity of teachers in the teaching and learning process through supervision assistance must be carried out on an ongoing basis by the person in charge of education, including the principal in charge of supervision.

The accomplishment of the educational goals that have been set in an educational institution is a shared aim that the principal and all teachers want to accomplish. There are many obstacles and challenges to achieving these objectives, both internal and external. One of the inner barriers is that of the teacher.

Based on the teaching conditions and typology as mentioned above, academic supervision of the principal would not be effective if the principal does not apply the correct approach to supervision. Facing the form of teacher who has a high degree of abstraction and a high level of dedication, the technique used is different when dealing with a teacher who has a high conception but a low level of obligation.

\section{Assessment of Principals as Instructional Supervisors for Enhancing Teacher Performance at SDIT} Baitul Jannah

The assessment is based on an accepted and accountable set of criteria. According to TR Morrison in Abdjul, cited by Nanang, there are three essential factors in the assessment concept: judgment, definition of the subject-matter of the assessment and defensible criteria. The objectives of the assessment include:

1. To gain the basis for assessment of the end of the working cycle, what has been done, what has not been accomplished and what needs special attention.

2. implement an excellent and efficient way of operating that leads the company to use educational services (human / labor, facilities / infrastructure, costs) economically.

3. Obtaining facts on difficulties, obstacles, deviations from certain aspects, - for example the annual program, learning progress.

Three major tasks are usually carried out by supervisors in the assessment of activities, namely: identification of evaluation objectives, preparation of evaluation design and technique, and calculation. SuharsimiArikunto listed the assessment activities of the program carried out by this research supervisor. The assessment process is an attempt to discover facts and truths; it must be objective and logical in its implementation; the principles of the scientific method must be implemented. Several program review methods are typically used by managers to find follow-up results, namely: (a) testing, (b) observation, (c) self-reporting, (d) self-assessment, and (e) peers. 
There are also a number of standards that supervisors must uphold in carrying out the assessment process, namely:

1. Comprehensive, the assessment needs to be carried out thoroughly. Both operation variables and relevant aspects must be clearly outlined in the comprehensive indicators.

2. In order to obtain complete information, cooperation between the evaluation subject and the evaluation object is necessary.

3. Continuous assessment, applicable to the curriculum, should be carried out on an ongoing basis, targeting all phases of action and mutually sustainable.

4. Objective that is not influenced by things that can confuse calculation and decision.

5. Humanist, who presents the dimensions of humanity

6. Secure, that is, it should preserve the privacy of individuals, not spread fears among artifacts under supervision.

As the final stage of the supervisory period, the follow-up to the follow-up program for the next year is to be decided. Monitoring follow-up shall be obtained on the basis of a comprehensive assessment of all supervision activities for a period of one year.

\section{CONCLUSION}

\section{Planning for academic supervision by the principal would improve the performance of teachers at SDIT Baitul Jannah.}

1) The school principal's approach to effective teaching preparation is collaborative. That is to suggest, it is compiled jointly by the principal and the teachers of all teachers.

2) Preparation for academic supervision of the Principal shall be formulated on the basis of the findings of the review of the assessment of the curriculum and the evaluation of the implementation.

3) The academic supervision plan of the Principal shall be formulated at the beginning of the school year by first defining the issues, setting the goals and setting the time of execution laid down in a supervision schedule of two semesters, including semester and even semester education programs;

4) academic supervision planning of the Principal must include aspects of teacher success, such as teaching preparation, learning implementation and learning outcome evaluation.

2. Implementation of academic supervision by the principal to boost the performance of teachers at SDIT Baitul Jannah

1) Using indirect monitoring strategies through KKG meetings, monthly meetings, group work, visits to the teacher's residence to create more intense communication;

2) Use direct supervision methods, by class visits, carried out in accordance with the schedule defined with the instructor. The aim of the visit was to specifically decide the adjustment between the preparation of lessons and the direct learning process.

3) Senior Delegates Supervising the Responsibility of Senior Teachers Delegated

4) Conduct follow-up activities and follow up on the results of the supervision implementation phase

\section{Evaluation of academic supervision by the Principal in Enhancing Teacher Efficiency at SDIT Baitul Jannah}

1) The assessment of academic supervision at SDIT BaitulJannah shall be carried out on a periodic basis, both at the end of the semester and at the end of the semester following the implementation of the predetermined semester programed.

2) The assessment results of the implementation of academic supervision at SDIT BaitulJannah are used to: develop the supervision program in the following year, follow up on the challenges encountered by teachers, find the best solution to and teacher with different characters and abilities. 


\section{ACKNOWLEDGMENTS}

The writers are grateful to the University of Lampung and SDIT Baitul Jannah, as well as to the educational administration and to all my colleagues that have supported me in creating this journal especially HepiSetiawan that always support me in making this journal. I also would like to thank Dr. Sowiyah, M.Pd and Dr. Dedy Hermanto Karwan, M.M. for their valuable advice.

\section{REFERENCES}

[1] Mulyasa, E. 2013. Menjadi Kepala Sekolah Profesional, Bandung; PT. Remaja Rosdakarya.

[2] Muhaimin. 2005. PengembanganKurikulumPendidikan Agama Islam, Di Sekolah, Madrasah danPerguruanTinggi; Jakarta :RajawaliPers.

[3] Moleong, L. 2014. Metodologi Penelitian Kualitatif. Edisi Revisi. Bandung: PT Remaja Rosdakarya

[4] Nanang, F. 2014. Landasan Manajemen Pendidikan. Bandung : Remaja Rosdakarya.

[5] Glickman, C., Gordon, S.Ross-Gordon.J (2010). SuperVison: and instructional leadership. (8th ed).Needham Heights, MA: Allyn \& Bacon.

[6] Arikunto, Suharsimi. (2010). Prosedur penelitian: Suatu pendekatan praktik. Jakarta: Rineka Cipta 